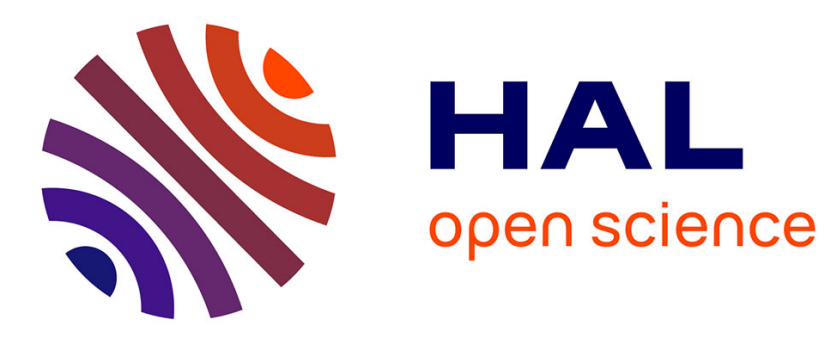

\title{
Enhanced antibacterial activity of carbon dots functionalized with ampicillin combined with visible light triggered photodynamic effects
}

Roxana Jijie, Alexandre Barras, Julie Bouckaert, Nicoleta Dumitrascu, Sabine Szunerits, Rabah Boukherroub

\section{To cite this version:}

Roxana Jijie, Alexandre Barras, Julie Bouckaert, Nicoleta Dumitrascu, Sabine Szunerits, et al.. Enhanced antibacterial activity of carbon dots functionalized with ampicillin combined with visible light triggered photodynamic effects. Colloids and Surfaces B: Biointerfaces, 2018, 170, pp.347 - 354 . 10.1016/j.colsurfb.2018.06.040 . hal-01925065

\section{HAL Id: hal-01925065 \\ https://hal.science/hal-01925065}

Submitted on 2 Dec 2019

HAL is a multi-disciplinary open access archive for the deposit and dissemination of scientific research documents, whether they are published or not. The documents may come from teaching and research institutions in France or abroad, or from public or private research centers.
L'archive ouverte pluridisciplinaire HAL, est destinée au dépôt et à la diffusion de documents scientifiques de niveau recherche, publiés ou non, émanant des établissements d'enseignement et de recherche français ou étrangers, des laboratoires publics ou privés. 


\title{
Enhanced antibacterial activity of carbon dots functionalized with ampicillin combined with visible light triggered photodynamic effects
}

\author{
Roxana Jijie, ${ }^{1,2}$ Alexandre Barras, ${ }^{1}$ Julie Bouckaert, ${ }^{3}$ Nicoleta Dumitrascu, ${ }^{2}$ Sabine Szunerits ${ }^{1}$ and \\ Rabah Boukherroub ${ }^{1 *}$ \\ ${ }^{1}$ Univ. Lille, CNRS, Central Lille, ISEN, Univ. Valenciennes, UMR 8520, IEMN, F-59000 Lille, \\ France \\ ${ }^{2}$ Iasi Plasma Advanced Research Center (IPARC), Faculty of Physics, AlexandruIoanCuza \\ University of Iasi, Bd. Carol I no. 11, Iasi, 700506, Romania \\ ${ }^{3}$ Unité de Glycobiologie Structurale et Fonctionnelle (UGSF), UMR 8576 du CNRS et Université \\ Lille, 50 Av. de Halley, 59658 Villeneuve d'Ascq, France
}

\begin{abstract}
In the last years, carbon-based nanomaterials have attracted considerable attention in a wide range of fields, particularly in biomedicine, owing to their remarkable photo-physical and chemical properties. In this study, we demonstrate that amine-terminated carbon dots $\left(\mathrm{CDs}-\mathrm{NH}_{2}\right)$ functionalized with ampicillin (AMP) offer a new perspective for antibacterial treatment. The amine-functionalized carbon dots were used as a carrier for immobilization and delivery of ampicillin (CDs-AMP) and as a visible light-triggered antibacterial material. Additionally, AMP immobilization on the CDs- $\mathrm{NH}_{2}$ surface improves its stability in solution as compared to free AMP. The AMP conjugated CDs platform combines the antibacterial function of AMP and conserves the intrinsic theranostic properties of $\mathrm{CDs}-\mathrm{NH}_{2}$. Therefore, the AMP immobilized onto $\mathrm{CDs}-\mathrm{NH}_{2}$ surface together with the generation of moderate quantities of reactive oxygen species under visible light illumination is very effective to inactivate the growth of Escherichia coli.
\end{abstract}

Keywords: Carbon dots; Ampicillin; Bactericidal activity; Escherichia coli; PDT

*To whom correspondence should be sent: rabah.boukherroub@univ-lille1.fr 


\section{Introduction}

The increase of multidrug-resistant bacteria infections represents an important biomedical challenge, demanding the development of alternative antibacterial-based platforms for which pathogens will not be able to develop resistance. In some situations, even the aggressive antibiotic treatment is not able to eradicate the infection due to the ability of bacteria to form biofilms.

In recent years, antimicrobial nanoparticles (NPs) [1], nano-sized carriers for the delivery of therapeutic agents [2] or light-responsive NPs [3-5] offer new approaches to fight against infectious diseases. Among the various nanoparticles, fluorescent carbon dots (CDs) open promising avenues for bacteria detection, imaging and inactivation due their remarkable optical properties, their surface versatility and good biocompatibility [6-14]. For example, Mehta et al.[11] reported that CDs, synthesized by using S. officinarum juice at $120{ }^{\circ} \mathrm{C}$, acted as excellent fluorescent probes for imaging of Escherichia coli (E. coli) bacteria. Amphiphilic CDs [7] and PEG-passivated CDs [12] revealed also their potential as fluorescent markers for bacterial detection and imaging. Zhong et al. [13] employed CDs modified with vancomycin for assaying Staphylococcus aureus (S. aureus). Dou et al. [14] showed that quaternary linear and branched polyethyleneimine passivated CDs exhibit promising antibacterial activity against both Gramnegative and Gram-positive bacteria.

Up to date, a limited attention has been paid for the use of fluorescent CDs as drug delivery vehicles [8, 15-18]. This also applies for their application for photodynamic/photothermal (PDT/PTT) therapy and particularly when it comes to the treatment of bacterial infections. The advantage of antimicrobial PDT includes equal killing efficiency independent of antibiotic resistance, the repetition of therapy without cumulative toxicity, and high spatial control. There has been much effort in the design of effective platforms for the treatment of cancer using CDs in combination with conventional photosynthesizers (PS) such as protoporphyrin I [19] or zinc phthalocyanine [20], while less effort has been devoted to the intrinsic photodynamic and/or antibacterial properties of CDs. The effect of surface charge (negative, neutral and positive) of CDs on the growth of Escherichia coli (E. coli) and the mechanism of antibacterial activity induced by these carbon nanostructures was investigated by Bing and coworkers [21]. Upon $6 \mathrm{~h}$ incubation of $E$. coli with the CDs, it was found that the positively charged CDs exhibited the strongest bactericidal activity, while the negatively charged and uncharged CDs had almost no 
bactericidal activity. A mechanistic study revealed that the bacteria exhibited characteristic markers of apoptosis upon treatment with the positively and negatively charged CDs, similar to those encountered upon treatment with common antibiotics [21]. CDs, prepared from Metronidazole (a wide spectrum antibiotic against obligate anaerobes, including Peptostreptococcus micros, Prevotella intermedia, P. gingvivalis and Fusobacterium) as the carbon source using hydrothermal conditions, displayed inhibition growth of $P$. gingvivalis [22]. Yang et al. [23] prepared quaternary ammonium functionalized CDs by conjugating lauryl betaine (BS-12) to amine-terminated CDs using the common NHS/EDC coupling chemistry. The developed material exhibited good fluorescence emission for simultaneous detection and inhibition of Gram-positive bacteria. Sattarahmady et al. [24] demonstrated that the bactericidal effect of CDs can be accelerated by near infrared (NIR, $808 \mathrm{~nm}$ ) irradiation. The NIR irradiation caused an increase of the solution temperature, inducing ROS production and cell wall damage.

In the present study, we have focused on the design and characterization of multifunctional CDs and investigated their antibacterial activity. Till now, various starting materials and synthetic routes to prepare CDs have been developed. These methods can be classified as topdown [12, 25-29] or bottom-up approaches [13, 30, 31]. Among them, the hydrothermal synthesis is mostly used, because it is a simple and efficient way to prepare CDs [6, 25, 32-36]. Recent studies have demonstrated that biocompatible multifunctional CDs may be prepared by using biological precursors [37-43], called green chemistry concept.

In this work, amine-functionalized carbon dots $\left(\mathrm{CDs}-\mathrm{NH}_{2}\right)$ were synthesized by a simple hydrothermal treatment of citric acid and ethylenediamine. The primary amine groups on the $\mathrm{CDs}-\mathrm{NH}_{2}$ surface were further used for the covalent linking of ampicillin (AMP), a $\beta$-lactam antibiotic, to produce CDs-AMP nanostructures. The immobilization of AMP onto the CDs- $\mathrm{NH}_{2}$ surface was supported by UV-Vis spectrophotometry, Fourier transform infrared spectroscopy (FTIR), atomic force microscopy (AFM), X-ray photoelectron spectroscopy (XPS), thermogravimetric analysis (TGA), zeta potential and dynamic light scattering (DLS) measurements. The antibacterial activity of $\mathrm{CDs}-\mathrm{NH}_{2}$ and CDs-AMP conjugate with and without visible light illumination was evaluated using the E. coli K12 - MG 1655 strain by cell growth measurements, standard plate count method and fluorescence-based cell dead/live assay. Our results demonstrated the potential of CDs-AMP as an effective platform for bacteria eradication. The lowest concentration of AMP necessary to inhibit the growth of $E$. coli cells in the case of 
CDs-AMP conjugate $\left(14 \mu \mathrm{g} \mathrm{mL} \mathrm{m}^{-1}\right)$ was improved compared to free AMP $\left(25 \mu \mathrm{g} \mathrm{mL}^{-1}\right)$, indicating the advantage of the CDs-AMP conjugate. In addition, we demonstrated that exposure of CDs-AMP to visible light enhances its bactericidal activity. To the best of our knowledge, there are no reports on the use of a platform that combines the intrinsic photodynamic properties of CDs with the antibacterial function of antibiotics loaded on their surface to inhibit the growth of pathogens. The results from this study highlighted the enhanced stability of AMP loaded on the CDs as compared to free AMP in addition to increased antibacterial activity upon visible light irradiation. The existence of a large panel of antibiotics and precursors for CDs synthesis holds great promise for the development of multifunctional nanostructures for combating bacterial infections.

\section{Experimental}

\subsection{Materials}

Citric acid, ethylenediamine, 9,10-anthracenediylbis(methylene)dimalonic acid (ABDA), ampicillin (AMP), $N$-(3-dimethylaminopropyl)- $N$ '-ethylcarbodiimide hydrochloride $(\mathrm{EDC} \cdot \mathrm{HCl})$, $N$-hydroxysuccinimide (NHS), acetic acid, sodium acetate, ninhydrin, potassium cyanide (KCN), pyridine, phenol, quinine sulfate, Hoechst 33342, and paraformaldehyde were purchased from Sigma-Aldrich and used as received.

\subsection{Synthesis of amine-functionalized carbon dots (CDs-NH2)}

Amine-functionalized carbon dots were synthesized following a method similar to that reported by Zhu et al.[44]. In brief, citric acid (2.1 g) and ethylenediamine $(670 \mu \mathrm{L})$ were dissolved in Milli-Q water $(20 \mathrm{~mL})$. Then the mixture was transferred into a Teflon-lined autoclave $(125 \mathrm{~mL}$ acid digestion vessel no. 4748 , Parr, France) and heated at $250{ }^{\circ} \mathrm{C}$ for 5 h. The resulting product was cooled to room temperature and dialyzed against Milli-Q water using a cellulose ester dialysis membrane for 3 days (Biotech $\mathrm{CE} \mathrm{N}^{\circ} 131093$, pore size 500-1000 Da) in order to remove unreacted small molecules. Then, dry mass of $200 \mu \mathrm{L}$ solution was weighted by Sartorius microbalance (TG 209 F3 Tarsus, Netzsch). The yield was about $60 \%$ and the stock solution was stored at $4{ }^{\circ} \mathrm{C}$.

\subsection{Conjugation of ampicillin onto amine-functionalized carbon dots (CDs-AMP)}


Ampicillin was dissolved in PBS at a concentration of $1 \mathrm{mg} \mathrm{mL}^{-1}$. The carboxyl groups of ampicillin were activated with an equimolar of $\mathrm{EDC} \cdot \mathrm{HCl}$ and $\mathrm{NHS}$ for $30 \mathrm{~min}$. $\mathrm{CDs}_{-} \mathrm{NH}_{2}$ dissolved in PBS at a concentration of $1 \mathrm{mg} \mathrm{mL}^{-1}$ and the ampicillin solution were mixed at a volume ratio of $2 / 1$ at room temperature overnight. After that, CDs-AMP conjugate solution was dialyzed (Biotech $\mathrm{CE} \mathrm{N}^{\circ} 131093$, pore size 500-1000 Da) against Milli-Q water to remove unreacted ampicillin and kept at $4{ }^{\circ} \mathrm{C}$ until use.

\subsection{Characterization}

Atomic force microscopy (AFM) measurements (NT-MDT Solver Pro-M type apparatus) were carried out in ambient air, in the tapping (non-contact) mode, using commercial standard siliconnitride tip with a radius of approximately $10 \mathrm{~nm}$ (NT-MDT NGS01/Au). The sample was prepared by dropping an aqueous $\mathrm{CDs}-\mathrm{NH}_{2}$ suspension onto a silicon surface and dried at $37^{\circ} \mathrm{C}$.

Size and zeta-potential measurements were performed using a Zetasizer Nano-ZS (Malvern Instruments Inc. Worcestershire, UK). CDs-NH 2 were diluted to $10 \mu \mathrm{g} \mathrm{mL}^{-1}$ and measured in Milli-Q water at $\mathrm{pH}$ 7.0.

UV-Vis spectroscopic measurements were carried out using a Perkin Elmer Lambda UV/Vis 950 dual-beam spectrophotometer operating at a resolution of $1 \mathrm{~nm}$. The UV-Vis spectra were recorded in quartz cuvettes of $1 \mathrm{~cm}$ path length between 200 and $800 \mathrm{~nm}$.

Emission fluorescence spectra were recorded between 220 and $800 \mathrm{~nm}$ using a Cary Eclipse spectrometer (Agilent, France). Solutions were excited from 300 to $400 \mathrm{~nm}$ in a $20 \mathrm{~nm}$ increment excitation (excitation and emission slit: $5 \mathrm{~nm}$, scan rate: $600 \mathrm{~nm} / \mathrm{min}$ ).

Thermogravimetric analysis (TGA) was carried out on a TG 209 F3 Tarsus Netzsch in the temperature range of 30 to $980{ }^{\circ} \mathrm{C}$ using an $\mathrm{Al}_{2} \mathrm{O}_{3}$ crucible under nitrogen flow ( $\left.20 \mathrm{~mL} \mathrm{~min}{ }^{-1}\right)$ with a heating rate of $10^{\circ} \mathrm{C} / \mathrm{min}$.

Fourier transform infrared (FTIR) spectra were recorded using a ThermoScientific FTIR instrument (Nicolet 8700) in the range between 650 and $4000 \mathrm{~cm}^{-1}$ at a spectral resolution of $6 \mathrm{~cm}^{-1} .1 \mathrm{mg}$ of dried CDs- $\mathrm{NH}_{2}$ was mixed with $200 \mathrm{mg}$ of $\mathrm{KBr}$ powder in an agar mortar. The mixture was pressed into a pellet under 7 tons of load for 2-4 min, and the spectrum was recorded immediately. A total of 64 accumulative scans were collected. The signal from a pure $\mathrm{KBr}$ pellet was subtracted as a background. 
X-ray photoelectron spectroscopy (XPS) measurements were performed with a Theta Probe spectrometer (Thermo Fisher Scientific) spectrometer using a monochromatic Al Ka X-ray source $(1486.6 \mathrm{eV})$ under a vacuum of about $2 \times 10^{-6} \mathrm{~Pa}$ at a photoelectron take-off angle of $45^{\circ}$.

SEM images of pathogens were recorded using a Zeiss Compat Merlin instrument and secondary electron detector at 2 and $5 \mathrm{kV}$ under high vacuum. The biological samples were fixed with $1 \%$ glutaraldehyde solution for $30 \mathrm{~min}$ in the dark at room temperature and then coated with $5 \mathrm{~nm}$ platinum.

\subsection{Quantum yield measurements}

The fluorescence quantum yield of CDs- $\mathrm{NH}_{2}$ (in PBS) was determined by the slope method [44] by comparing the integrated photoluminescence intensity and absorbance of each sample with that of a reference. Quinine sulfate $\left(0.1 \mathrm{M} \mathrm{H}_{2} \mathrm{SO}_{4}\right.$ as a solvent; $\left.\mathrm{QY}=0.54\right)$ was chosen as the reference. The quantum yield was calculated using the following equation:

$$
\phi_{\mathrm{x}}=\phi_{\mathrm{st}}\left(\mathrm{K}_{\mathrm{x}} / \mathrm{K}_{\mathrm{st}}\right)\left(\eta_{\mathrm{x}} / \eta_{\mathrm{st}}\right)^{2}
$$

where $\phi$ is the quantum yield, $K$ is the slope determined by the curves and $\eta$ is the refractive index of the solvent. The subscript "st" refers to the standard with the known quantum yield and " $\mathrm{x}$ " for the sample. In order to minimize re-absorption effects, absorption in the $10 \mathrm{~mm}$ fluorescence cuvette was kept below 0.10 at the excitation wavelength $(360 \mathrm{~nm})$. For these aqueous solutions, $\eta_{\mathrm{x}} / \eta_{\mathrm{st}}=1$. A series of concentrations of the reference and sample were measured to obtain the slopes of the curves.

\subsection{Quenching of CDs- $\mathrm{NH}_{2}$ fluorescence in solution}

Different concentrations of ampicillin were mixed with $\mathrm{CDs}-\mathrm{NH}_{2}$ and after $12 \mathrm{~h}$, the fluorescence spectra of the samples were recorded at $350 \mathrm{~nm}$ excitation wavelength.

\subsection{Quantification of primary amine groups by a modified Kaiser test}

The primary amine groups were quantified using a modified photometric assay based on the Kaiser test [45]. Briefly, the amine-functionalized CDs- $\mathrm{NH}_{2}$ powder $\left(0.25-1 \mathrm{mg} \mathrm{mL} \mathrm{mL}^{-1}\right)$ was dissolved in $1 \mathrm{~mL}$ Milli-Q water. To this suspension was added $1 \mathrm{~mL}$ of the buffer solution (1) and then sonicated for $15 \mathrm{~min}$. After that, $1 \mathrm{~mL}$ of $\mathrm{KCN}$ solution (2) and $1 \mathrm{~mL}$ of phenol solution 
(3) were added and the suspension was heated at $120{ }^{\circ} \mathrm{C}$ for $10 \mathrm{~min} ; 1 \mathrm{~mL}$ of ninhydrin solution (4) was added and heated for another $10 \mathrm{~min}$. After the solution was cooled to room temperature, $5 \mathrm{~mL}$ of ethanol were added (5).

1. Buffer solution: $36 \mathrm{~g}$ of sodium acetate were dissolved in $6.9 \mathrm{~mL}$ of acetic acid and filled with Milli-Q water until a volume of $100 \mathrm{~mL}$.

2. KCN solution: $2 \mathrm{~mL}$ of $0.03 \mathrm{M} \mathrm{KCN}$ solution were diluted to a volume of $100 \mathrm{~mL}$ with pyridine.

3. Phenol solution: $80 \mathrm{~g}$ of phenol were dissolved in $20 \mathrm{~mL}$ of ethanol.

4. $5 \%$ ninhydrin solution: $5 \mathrm{~g}$ of ninhydrin were dissolved in $100 \mathrm{~mL}$ of ethanol.

5. $60 \%$ ethanol solution.

\subsection{Singlet oxygen $\left({ }^{1} \mathrm{O}_{2}\right)$ detection}

Singlet oxygen generation was measured through the chemical oxidation of an aqueous solution of 9,10-anthracenediylbis(methylene)dimalonic acid (ABDA, $10 \mu \mathrm{M}$ ) in presence of $\mathrm{CDs}_{-\mathrm{NH}_{2}}$ under visible light irradiation. The decrease in the ABDA absorbance at $262 \mathrm{~nm}$ was monitored at several time intervals. The light emitted by a visible lamp (Spot Light Source, $420-700 \mathrm{~nm}$, L9566-03, Hamamatsu, Japan) was focused onto a quartz cuvette $(1 \mathrm{~cm}$ path length and $2 \mathrm{~mm}$ width) containing $1 \mathrm{~mL}$ of the solution. The intensity of the light was measured using a PM600TM laser Fiber Power Meter (Coherent Inc., USA). All the experiments were performed in triplicate.

\subsection{Cell culture, cytotoxicity assay and cellular uptake}

\section{Cytotoxicity assay}

The HeLa cell line, derived from cervical carcinoma from a 31 year old female [ATCC® CCL$2^{\mathrm{TM}}$, ECACC, Sigma Aldrich, Saint-Quentin Fallavier, France] was cultured and maintained in Dulbecco's Modified Eagle's medium (DMEM, Gibco®) supplemented with $10 \%$ fetal bovine serum (FBS, Gibcoß) and $1 \%$ penicillin-streptomycin (Gibco®) in a humidified incubator at $37{ }^{\circ} \mathrm{C}$ and $5 \% \mathrm{CO}_{2}$. Cells were seeded at a density of $10^{4}$ cells/well in a 96-well plate and grown for $24 \mathrm{~h}$ before assay. The culture medium was replaced with a fresh medium that contains the $\mathrm{CDs}-\mathrm{NH}_{2}$. The final concentration of CDs- $\mathrm{NH}_{2}$ was $12.5,25,50,100$ or $200 \mu \mathrm{g} \mathrm{mL} \mathrm{m}^{-1}$. After 24 $\mathrm{h}$, the old medium was aspirated and cells were washed three times with PBS. The cell viability 
was evaluated using Uptiblue (Interchim) method. Briefly, $10 \mu \mathrm{L}$ of the Uptiblue solution were added to each well containing $100 \mu \mathrm{L}$ of DMEM with $10 \% \mathrm{FBS}$ and the plate was incubated for $4 \mathrm{~h}$ in the humidified incubator. The fluorescence of each well at $590 \mathrm{~nm}$ was measured using a microplate reader (PHERAstar FS, BMG LABTECH GmbH, Germany). Each condition was replicated five times and the mean absorbance value of non-exposed cells was taken as $100 \%$ cellular viability.

\section{Cell imaging}

HeLa cells were seeded in a 24-well plate with sterile coverslips at the bottom at a density of $2 \times 10^{5}$ cells/well and grown for $24 \mathrm{~h}$ before assay. The $\mathrm{CDs}-\mathrm{NH}_{2}$ solution was diluted to a final concentration of $200 \mu \mathrm{g} \mathrm{mL} \mathrm{m}^{-1}$ by DMEM without serum. After incubation for $1 \mathrm{~h}$ at $37{ }^{\circ} \mathrm{C}$ and $4{ }^{\circ} \mathrm{C}$, the HeLa cell monolayer was washed three times with PBS, fixed on a glass slide with $4 \%$ paraformaldehyde at room temperature for $15 \mathrm{~min}$ and then stained with $5 \mu \mathrm{g} \mathrm{mL}^{-1}$ DAPI in PBS at room temperature in the dark for $5 \mathrm{~min}$. After gentle washing with PBS (3 times), the coverslips were mounted on glass slides and observed using a Leica AF6000X fluorescence microscope equipped with an Andor iXon 885 Camera and by using an oil immersion objective $(100 \times ; 1.4$ NA objective). The fluorescence signal was acquired using a dual band excitation and emission filter sets for DAPI $\left(\lambda_{\text {ex }} / \lambda_{\text {em }}: 350 / 460 \mathrm{~nm}\right)$ and green fluorescent protein $(\mathrm{GFP})\left(\lambda_{\mathrm{ex}} / \lambda_{\mathrm{em}}\right.$ : 492/534 nm). All the images were further processed using Leica LAS AF Lite software.

\subsection{The antibacterial activity of CDs-AMP conjugate}

\section{Bacteria growth conditions}

A single E. coli K12 - MG 1655 colony from LB agar plate was inoculated overnight in LB (Luria-Bertani) medium at $37^{\circ} \mathrm{C}$ with moderate shaking. The pre-culture was diluted 50 -fold and allowed to continue for another 3 - $4 \mathrm{~h}$ until the $\mathrm{OD}_{600 \mathrm{~nm}}$ had reached 0.6-1.

\section{Bacteria cell viability}

The antibacterial activity of AMP and CDs-AMP conjugate with or without visible light illumination was assessed using E. coli K12 - MG 1655 strain by cell growth measurements based on the optical density at $600 \mathrm{~nm}$ and by plating method to quantify the viable cell number. 
Briefly, E. coli cells were inoculated in LB medium with different concentrations of carbon dots $\left(\mathrm{CDs}-\mathrm{NH}_{2}\right)$, ampicillin (AMP), ampicillin mixed with $\mathrm{CDs}-\mathrm{NH}_{2}$, and CDs-AMP conjugate at $37^{\circ} \mathrm{C}$ for $6 \mathrm{~h}$ and the growth was monitored by measuring the absorbance at $600 \mathrm{~nm}$.

A 10-fold dilution series of the bacterial solutions in phosphate buffer saline were spotted in $10 \mu \mathrm{L}$ aliquots on LB-agar medium. Visual counting of the number of colonies upon overnight incubation at $37^{\circ} \mathrm{C}$ allowed reading out the initial and final concentrations of the E. coli strain in $\mathrm{cfu} \mathrm{mL}^{-1}$. All the experiments were performed in triplicate.

\section{Fluorescence-based Cell Dead/Live assay}

The total amount of live and dead bacteria cells was determined with Live/Dead BacLight bacterial viability kit (Invitrogen). The samples were incubated in the dark at room temperature for 15 min with $3 \mu \mathrm{L}$ of two BacLight stains, a 1:1 mixture of SYTO 9 nucleic acid stain and propidium iodide. Then, $5 \mu \mathrm{L}$ of the stained bacteria suspension was deposited between a glass

slide and a cover slip. The slides were observed using a Leica AF6000 LX fluorescent microscope equipped with an Andor iXon 885 Camera using an oil immersion objective (100×; 1.4 NA objective). The fluorescence signal was acquired using a dual band excitation and emission filter sets for green fluorescent protein (GFP) and red fluorescent protein (mCherry). All the images were further processed using Leica LAS AF Lite software.

\section{Results and Discussion}

\section{Synthesis and characterization of CDs-AMP conjugate}

The strategy employed for the synthesis of the carbon dots is illustrated in Figure S1. It is based on the hydrothermal approach using citric acid as a carbon source and ethylenediamine as a surface passivation agent. This simple and efficient synthetic route leads directly to aminefunctionalized CDs. Moreover, the presence of primary amine groups in the CDs structure expands their application field through conjugation of therapeutic molecules.

We selected ampicillin, a $\beta$-lactam antibiotic, as an antibacterial model drug, owing to its broad spectrum range of bactericidal activity. The conjugation of AMP to the CDs- $\mathrm{NH}_{2}$ surface was achieved through the reaction of the carboxyl group of AMP with the amine groups of the CDs using EDC/NHS as cross-linking agents. 
The prepared CDs before and after conjugation with ampicillin (AMP) were characterized using atomic force microscopy (AFM) in tapping mode (Fig. S2). Under our experimental conditions, AFM imaging revealed the formation of round shape nanoparticles with an average height of $6 \pm 2 \mathrm{~nm}$. After chemical functionalization of the CDs- $\mathrm{NH}_{2}$ with ampicillin, the average height increased to $41 \pm 3 \mathrm{~nm}$, mostly due to CDs' partial aggregation.

According to DLS measurements, the $\mathrm{CDs}-\mathrm{NH}_{2}$ aqueous solution displays an average hydrodynamic diameter of $3.2 \pm 0.8 \mathrm{~nm}$ (Fig. S3). After conjugation with AMP, the average size of CDs-AMP reached $44 \pm 10 \mathrm{~nm}$, which is much larger than that of as-prepared $\mathrm{CDs}_{-} \mathrm{NH}_{2}$ due most likely to the formation of aggregated structures, similar to those reported in ref.[15]. The DLS measurements agree well with the AFM results.

The mean zeta potential of the CDs- $\mathrm{NH}_{2}$ varied from a positive $(+16 \pm 3 \mathrm{mV})$ to a negative ($17.5 \pm 3 \mathrm{mV}$ ) value with the $\mathrm{pH}$ varying from 3 to 8 . The isoelectric point of the carbon dots was determined to be around 3.7, which is quite similar with previously reported data [46, 47]. In addition, the surface zeta potential changed after the functionalization of the $\mathrm{CDs}-\mathrm{NH}_{2}$ with ampicillin at pH 7.0 from $+14 \pm 2 \mathrm{mV}$ to $-8 \pm 2 \mathrm{mV}$ (Table S1, Fig. S4).

It should be pointed out that the $\mathrm{CDs}-\mathrm{NH}_{2}$ remain stable in aqueous medium for at least two months at $4{ }^{\circ} \mathrm{C}$ without visible precipitation or a decrease in absorbance/fluorescence intensity (Fig. S5).

The UV-Vis and fluorescence spectra of CDs- $\mathrm{NH}_{2}$ and CDs-AMP conjugate are depicted in Figure 1A. UV-vis absorption spectrum of $\mathrm{CDs}-\mathrm{NH}_{2}$ exhibits three bands at 237, 342 and $450 \mathrm{~nm}$ due to the $\pi \rightarrow \pi^{*}$ transition of aromatic $\mathrm{C}=\mathrm{C}$ bond, $\mathrm{n} \rightarrow \pi^{*}$ transition of the $\mathrm{C}=\mathrm{O}$ bond and to amine-functionalized surface of the CDs [48-51], while the absorption of ampicillin is below $260 \mathrm{~nm}$.

It should be noted that simple mixing of CDs- $\mathrm{NH}_{2}$ with free AMP did not have any effect on their fluorescence properties (Fig. S6), whereas the conjugation of AMP to CDs- $\mathrm{NH}_{2}$ surface induced a decrease of fluorescence quantum yield from $32 \%$ to $19 \%$ (Fig. 1B).

The fluorescence spectra exhibit an excitation $\left(\lambda_{\mathrm{ex}}\right)$ independent emission $\left(\lambda_{\mathrm{em}}\right)$ behavior, which may originate from the CDs uniform size and from the homogeneous distribution of emissive sites (Fig. 2) [52]. The maximum fluorescence intensity was recorded at $445 \mathrm{~nm}$ under 
$340 \mathrm{~nm}$ excitation with a full width at half maximum (FWHM) of $\sim 76 \mathrm{~nm}$ for $\mathrm{CDs}-\mathrm{NH}_{2}$ and $\sim 82$ nm for CDs-AMP conjugate.
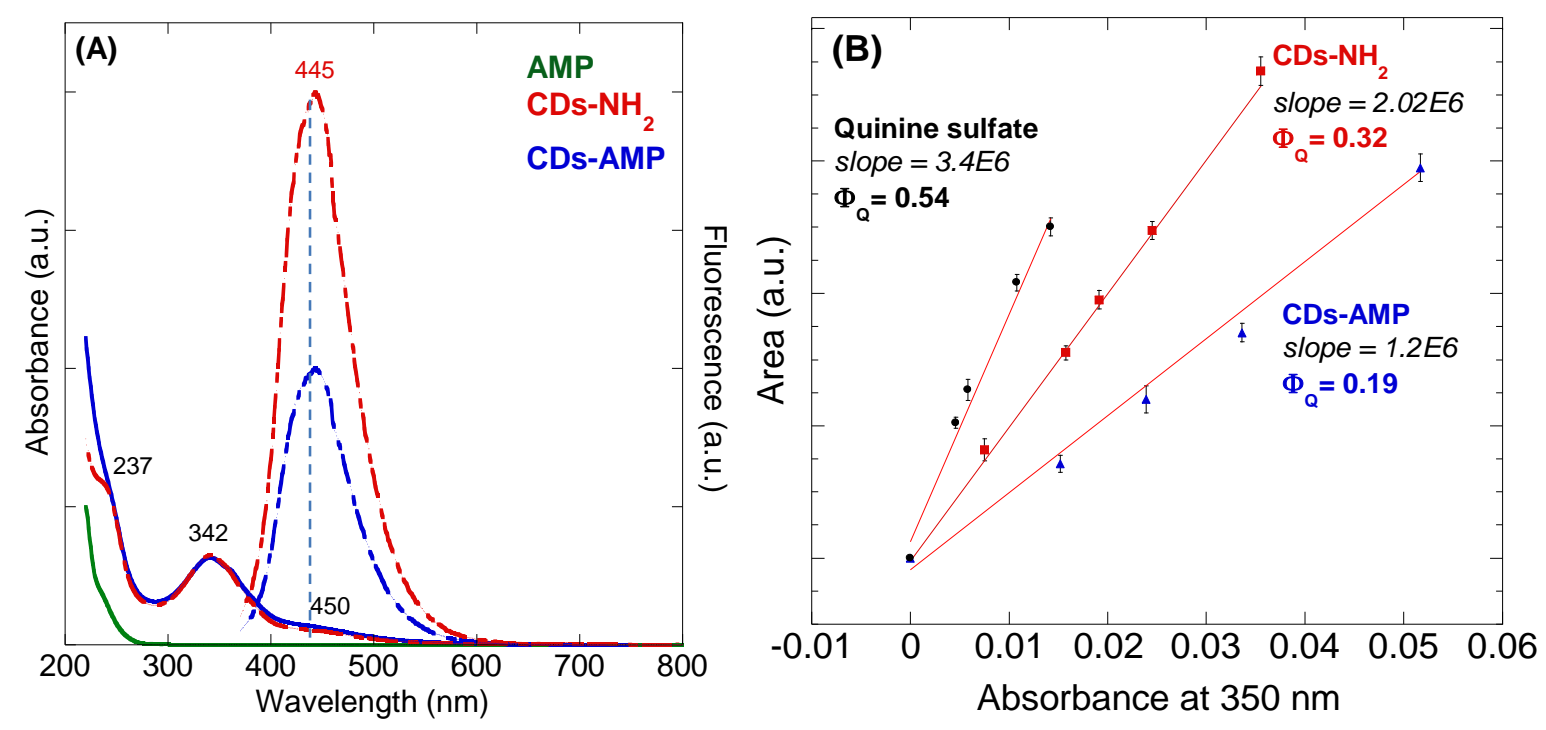

Figure 1. (A) UV-Vis absorption (solid lines) and fluorescence spectra (dash lines, $\lambda_{\mathrm{ex}}=350$ $\mathrm{nm}$ ) of AMP (green), CDs- $\mathrm{NH}_{2}$ (red) and CDs-AMP conjugate (blue) aqueous solutions.

(B) Plots of integrated fluorescence spectra against absorbance of quinine sulfate of $\mathrm{CDs}-\mathrm{NH}_{2}$ and CDs-AMP conjugate in PBS. The error bars represent the standard deviation of three independent experiments.
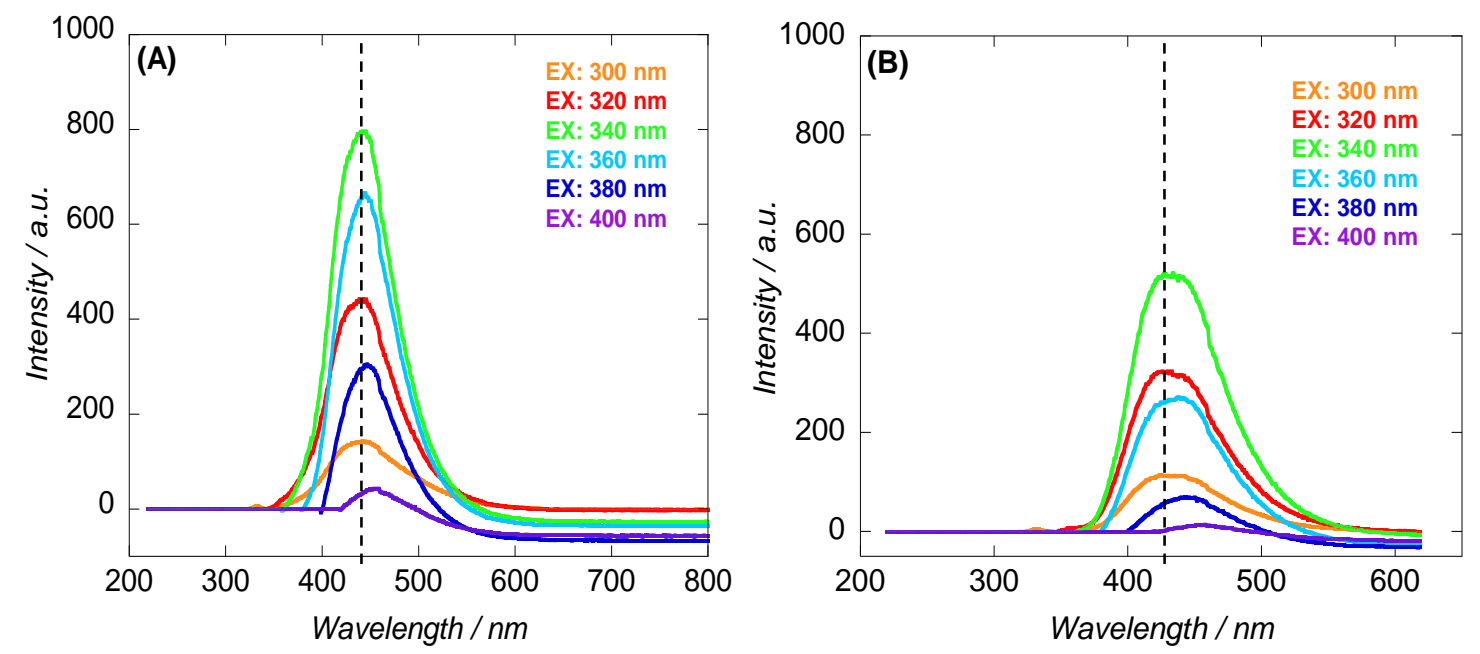

Figure 2. Fluorescence spectra of (A) $\mathrm{CDs}_{-} \mathrm{NH}_{2}$ and (B) CDs-AMP conjugate for different $\lambda_{\mathrm{ex}}$ wavelengths from 300 to $400 \mathrm{~nm}$ with a $20 \mathrm{~nm}$ increment. 
The thermal properties were probed through thermogravimetric analysis (TGA) measurements (Fig. S7). From the TGA results, the amount of AMP conjugated on the surface of the $\mathrm{CDs}_{-} \mathrm{NH}_{2}$ was estimated to be $14 \%$, corresponding to a loading efficiency of $28 \%$. A comparable result was reported by Krishanaet al.[15]; the amount of ciprofloxacin conjugated onto $1 \mathrm{mg}$ CDs modified glutamic acid was quantified as $96 \mu \mathrm{g}(\sim 10 \%)$. As can be seen in Fig. S7, the CDs-AMP conjugate decomposes at a faster rate compared to as-prepared $\mathrm{CDs}-\mathrm{NH}_{2}$ with a maximum weight loss recorded between 150 and $450{ }^{\circ} \mathrm{C}$, indicating the conjugation of AMP to CDs- $\mathrm{NH}_{2}$ surface.

The FTIR and XPS measurements were carried out to gain further insights into the chemical composition of as-prepared and AMP functionalized CDs-NH 2 . In the FTIR spectrum (Fig. S8), we can identify the characteristic absorption bands corresponding to stretching vibrations of $\mathrm{O}-\mathrm{H}$ (3650-3200 cm $\mathrm{cm}^{-1}$, aromatic C-H (3080-3030 $\left.\mathrm{cm}^{-1}\right)$, aliphatic C-H (3000-2840 cm $\left.\mathrm{cm}^{-1}\right), \mathrm{C}=\mathrm{O}(1800-$ $1650 \mathrm{~cm}^{-1}$ for carboxylic acids and $\beta$-lactones), C-C $\left(1297 \mathrm{~cm}^{-1}\right), \mathrm{C}-\mathrm{O}\left(1126 \mathrm{~cm}^{-1}\right)$ and C-S (700 $\mathrm{cm}^{-1}$ ). The absorption bands associated with the stretching and deformation vibrations of $\mathrm{C}-\mathrm{S}$, $\mathrm{NH}_{2}, \mathrm{C}=\mathrm{O}$ and $\mathrm{C}-\mathrm{N}$ (from $\beta$-lactam) reflect the conjugation of AMP onto CDs- $\mathrm{NH}_{2}$. The existence of amine-containing functional groups is confirmed by the stretching vibration and deformation bands of $v_{\mathrm{C}-\mathrm{N}}, v_{\mathrm{C}=\mathrm{N}}$ and $v_{\mathrm{N}-\mathrm{H}} / \delta_{\mathrm{N}-\mathrm{H}}$ centered at $3250,1640,1558,1395,1313,764$ and $735 \mathrm{~cm}^{-1}$, respectively.

The presence of primary amine groups is also validated by high-resolution XPS spectrum of the $\mathrm{N}_{1 \mathrm{~s}}$ region (Fig. S9) and a modified Kaiser test. According to the modified Kaiser test, the $\mathrm{NH}_{2}$ surface loading is about $0.7 \mathrm{mmol} \mathrm{g}^{-1}$, meaning that the maximum loading of AMP is 0.245 $\mathrm{g}$ per $1 \mathrm{~g}$ CDs (Fig. S10). From the TGA measurements, the amount of AMP conjugated onto $1 \mathrm{~g}$ CDs- $\mathrm{NH}_{2}$ was quantified as $0.14 \mathrm{~g}$, therefore the reaction yield is $57 \%$.

The XPS results are summarized in Table S2. Three peaks at 285.1, 399.1 and $532.1 \mathrm{eV}$ revealing the presence of carbon, nitrogen and oxygen, respectively, were observed in all the XPS survey spectra. The additional peak in the XPS survey spectrum of CDs-AMP conjugate, assigned to $S_{2 p}$, clearly indicates the successful conjugation of AMP to CDs surface.

The high resolution spectrum of the $\mathrm{S}_{2 \mathrm{p}}$ region of CDs-AMP shows the presence of $-\mathrm{C}-\mathrm{S}-\mathrm{C}$ and $-\mathrm{C}-\mathrm{S}(\mathrm{O})_{\mathrm{x}}-\mathrm{C}$-units, centered at 162.3 and $167.4 \mathrm{eV}$, respectively (Fig. 3A). The-C-S-C- unit 
displays two peaks at 161.7 and $163.1 \mathrm{eV}$ assigned to $S_{2 p 3 / 2}$ and $S_{2 p 1 / 2}$ splitting of the $S_{2 p}$ spin orbital, respectively. The presence of oxidized sulfur (S-O) suggests that ampicillin was partially oxidized. To rule out the possibility of CDs to oxidize AMP, we have recorded the XPS spectra of AMP powder (Fig. S11) and AMP solution (drop casted onto a silicon substrate) (Fig. 3C). While the high resolution XPS spectrum of the $S_{2 p}$ region of AMP powder displays only nonoxidized sulfur, the $S_{2 p}$ high resolution XPS spectrum of AMP that has been previously solubilized in an aqueous medium exhibits both non and oxidized components of sulfur. It is assumed that sulfur oxidation takes place upon the preparation of AMP solution (Fig. 3C) (it is generally recommended by the supplier to use AMP solution just after its preparation to limit its degradation).
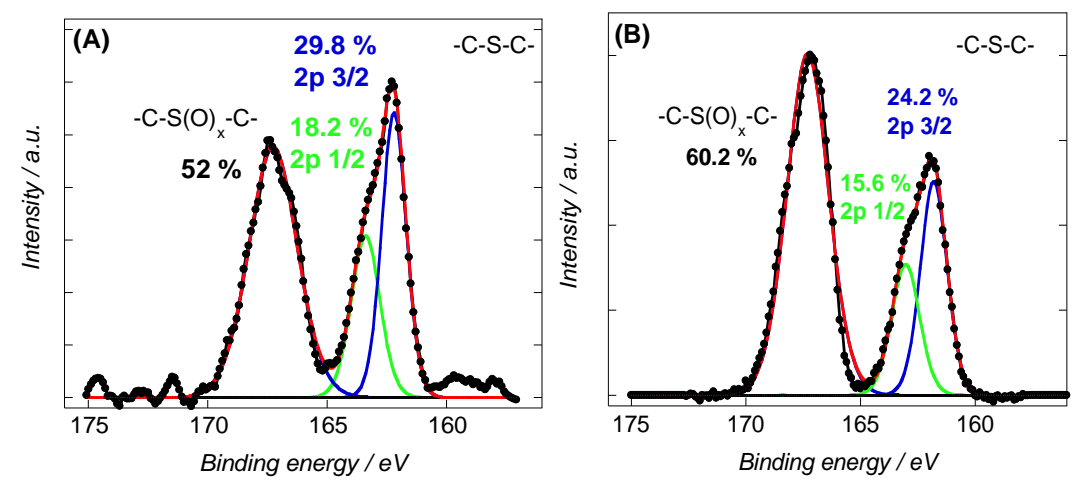

Figure 3. High resolution spectra of $S_{2 p}$ of (A) CDs-AMP conjugate, and (B) a solution of AMP drop casted onto a silicon substrate.

The $\mathrm{C}_{1 \text { s }}$ peak was deconvoluted into three main components assigned to $\mathrm{sp}^{2} \mathrm{C}-\mathrm{C}$ at $284.5 \mathrm{eV}$, oxygen/nitrogen and/or sulfur bonded carbon at $285.5 \mathrm{eV}$, and $\mathrm{C}=\mathrm{O} / \mathrm{C}=\mathrm{N}$ at $288.0 \mathrm{eV}$ for both CDs-NH 2 and CDs-AMP conjugate (Fig. S12).

As evidenced from the FTIR and XPS results, the as-synthesized CDs contain a large number of functional groups, including oxygen- and amino-containing groups.

\section{Antibacterial properties}

Before investigating the effect of the $\mathrm{CDs}_{-} \mathrm{NH}_{2}$ and CDs-AMP nanostructures on $E$. coli cells, their cytotoxicity and cellular uptake were evaluated on mammalian (HeLa) cells. As can be seen in Fig. 4, the amine-functionalized carbon dots can be easily internalized into the cells, crossing 
the cell membrane and spreading into the cytoplasm, with reduced toxicity. In agreement, with cytotoxicity study, no significant changes in cell viability were observed upon incubation of the cells with various $\mathrm{CDs}-\mathrm{NH}_{2}$ concentrations ranging from 12.5 to $200 \mu \mathrm{g} \mathrm{mL}^{-1}$ (Fig. S13). It was found that more than $90 \%$ of cells survive even at a nanoparticle concentration of $200 \mu \mathrm{g} \mathrm{mL}{ }^{-1}$ after $24 \mathrm{~h}$. Similarly, AMP, CDs-AMP and AMP (15\%) mixed with CDs did not show any apparent cytotoxicity for concentrations up to $200 \mu \mathrm{g} \mathrm{mL} \mathrm{mL}^{-1}$ (Fig. S13). The results clearly indicate that $\mathrm{CDs}-\mathrm{NH}_{2}$ and $\mathrm{CDs}-\mathrm{AMP}$ are suitable for biomedical applications.

In order to elucidate the uptake mechanism, $200 \mu \mathrm{g} \mathrm{mL} \mathrm{m}^{-1}$ of $\mathrm{CDs}^{-\mathrm{NH}_{2}}$ were incubated with HeLa cells at $37{ }^{\circ} \mathrm{C}$ and $4{ }^{\circ} \mathrm{C}$ for $1 \mathrm{~h}$, followed by staining of the nucleus with Hoechst 33342 (blue) and analysis by fluorescence microscopy (Fig. 4). Upon incubation of HeLa cells with $\mathrm{CD}-\mathrm{NH}_{2}$ for $1 \mathrm{~h}$ at $37{ }^{\circ} \mathrm{C}$, an apparent internalization of the $\mathrm{CDs}-\mathrm{NH}_{2}$ by HeLa cells was evidenced from the green fluorescence homogeneously distributed in the cytoplasm. This contrasts with the lower fluorescence intensity recorded upon incubation for $1 \mathrm{~h}$ at $4{ }^{\circ} \mathrm{C}$, because at this temperature, active uptake processes are normally arrested. The green fluorescence observed in the cytoplasm at $4{ }^{\circ} \mathrm{C}$ suggested that a small portion of the $\mathrm{CDs}_{-} \mathrm{NH}_{2}$ was internalized by passive penetration. The reduction in the fluorescence signal indicates that cellular uptake of $\mathrm{CDs}-\mathrm{NH}_{2}$ was not determined by a single mechanism; both passive penetration and endocytosis mechanism were responsible for cellular internalization of $\mathrm{CDs}-\mathrm{NH}_{2}$. Wang et al.[53] demonstrated that $6 \mathrm{~nm}$ mercaptosuccinic acid-coated CdTe quantum dots (MSA-QDs) entered the cells mainly by endocytosis, while part of the $2 \mathrm{~nm}$ QDs entered the cells by passive penetration.

Bright-field

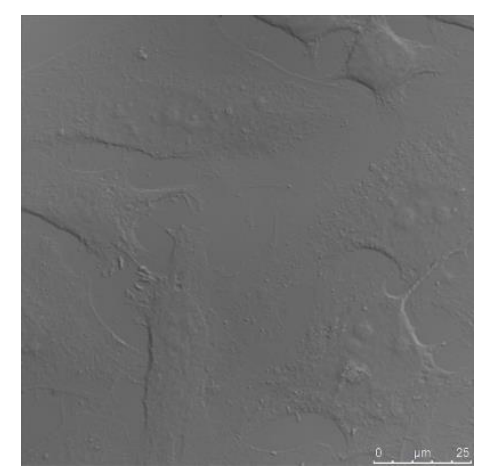

Fluorescence

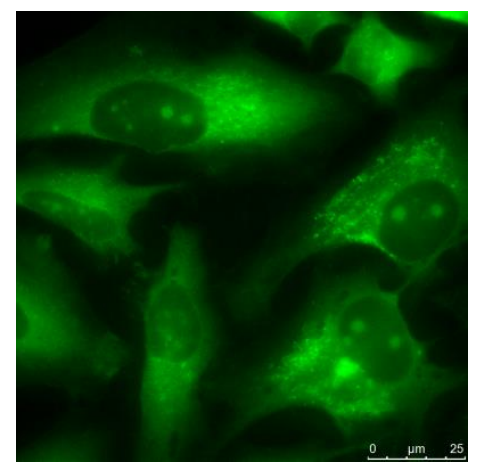

Overlay

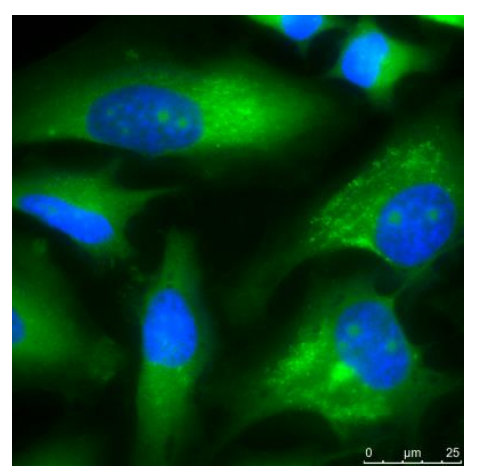



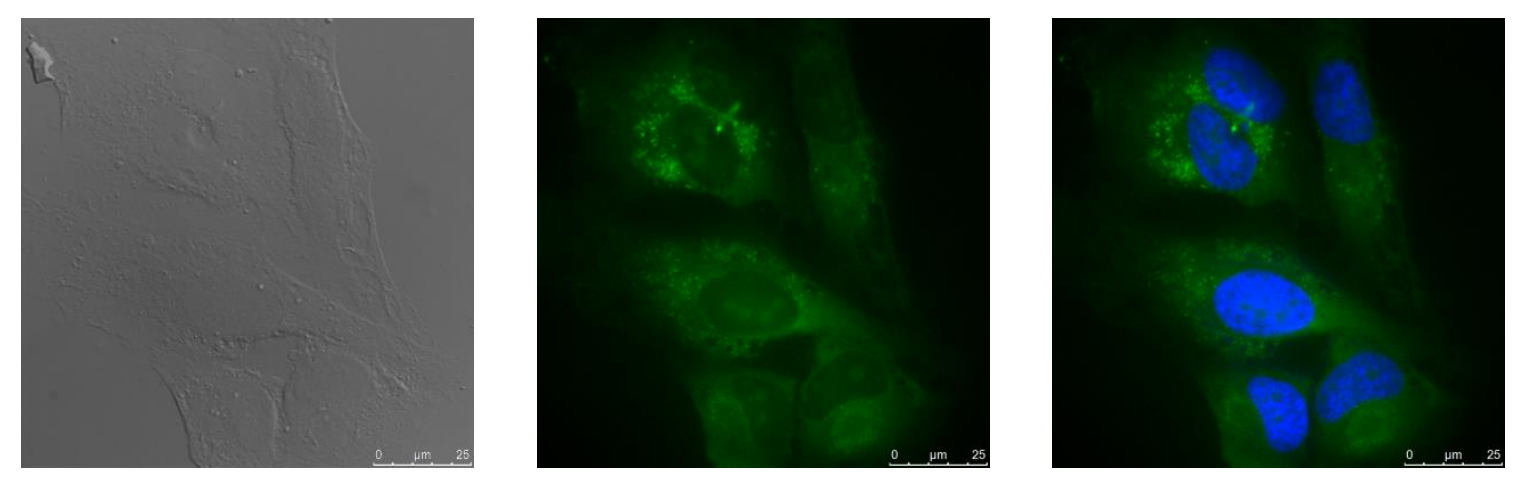

Figure 4. Fluorescence microscopy images of HeLa cells incubated with $200 \mu \mathrm{g} \mathrm{mL} \mathrm{m}^{-1}$ of CDs$\mathrm{NH}_{2}$ for $1 \mathrm{~h}$ at $37^{\circ} \mathrm{C}$ (upper) and $4{ }^{\circ} \mathrm{C}$ (lower). The green signal in all images corresponds to the amine-functionalized carbon dots; the nuclei of the cells incubated with $\mathrm{CDs}-\mathrm{NH}_{2}$ were stained with Hoechst 33342 (blue).

The antibacterial properties of $\mathrm{CDs}-\mathrm{NH}_{2}$ and $\mathrm{CDs}$-AMP conjugate with or without visible light illumination were evaluated using E. coli K12 - MG 1655 strain by cell growth measurements based on the optical density at $600 \mathrm{~nm}$, by plating method to quantify the viable cell number, and fluorescence-based cell dead/live assay; the green fluorescence correspond to live cells while the red fluorescence to dead cells. The fluorescence images in Fig. 5 revealed that the amine-functionalized carbon dots were not toxic, the bacterial cells remained viable upon exposure to $100 \mu \mathrm{g} \mathrm{mL}^{-1} \mathrm{CDs}-\mathrm{NH}_{2}$ for $6 \mathrm{~h}$. In contrast to CDs- $\mathrm{NH}_{2}$, the CDs-AMP exerted a pronounced bactericidal activity on E. coli. Furthermore, because of the bacterial membrane destruction, it was difficult to image them, the PI cannot penetrate bacterial membrane. This was additionally evidenced by SEM imaging, showing membrane disruption (Inset in Fig. 5).

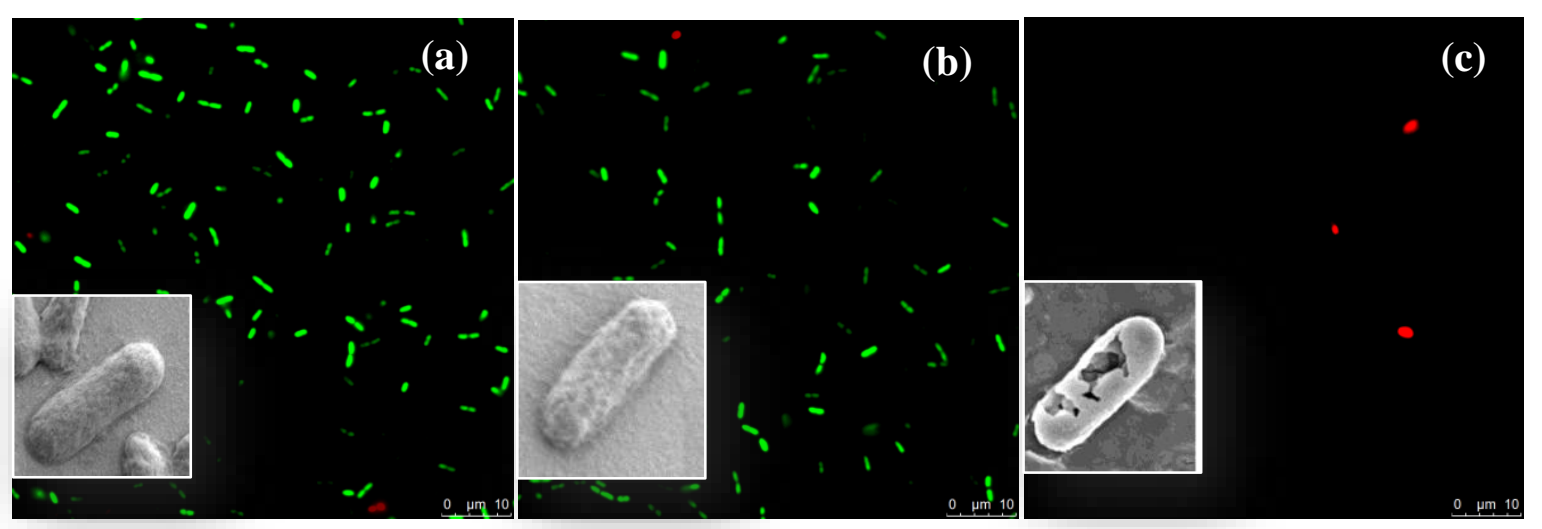


Figure 5. Viability of E. coli K12-MG 1655 imaged by the LIVE/DEAD ${ }^{\circ}$ BacLight ${ }^{\mathrm{TM}}$ assay for (a) control - without CDs, (b) with CDs- $\mathrm{NH}_{2}\left(100 \mu \mathrm{g} \mathrm{mL}^{-1}\right)$ and (c) with CDs-AMP $\left(100 \mu \mathrm{g} \mathrm{mL}^{1}\right)$. Inserts: SEM images of bacterial cell.

The covalent attachment of AMP to the CDs surface did not affect its antibacterial activity, but improved its efficacy through MIC reduction by $44 \%$ when compared to free AMP (Fig. 6A). Indeed, the lowest concentration of AMP necessary to inhibit the visible growth of E. coli cells in the case of CDs-AMP conjugate was $14 \mu \mathrm{g} \mathrm{mL}^{-1}$ as compared to $25 \mu \mathrm{g} \mathrm{mL}^{-1}$ using free AMP (Fig. 6B). The enhanced antibacterial activity of the CDs-AMP conjugate can be ascribed to its affinity to bind onto the bacterial cell wall which is more easily exposed to a large number of antibiotics molecules, causing its disruption, as can be seen in Fig. 5. It is known that the action mode of AMP is associated with cell wall synthesis, inhibiting the activity of the transpeptidase enzyme [54]. Our results are comparable to the reported data in the literature. It is found that the hybrid system comprising nanoparticles and antibiotics exhibited enhanced bactericidal activity and higher stability compared to free antibiotic drugs [16, 55-58].

The result was also confirmed by the antibacterial studies; compared with free AMP, the AMP conjugated onto CDs was still active against $E$. coli cells even after two weeks of storage at $4{ }^{\circ} \mathrm{C}$ in aqueous solution (Fig. S14). Similar results were reported by Rai et al.[59]; Au NPs increased the stability of cefaclor, preserving intact the antibacterial activity for 5 days, while after $9 \mathrm{~h}$ the activity of pure cefaclor in solution was only $11 \%$.
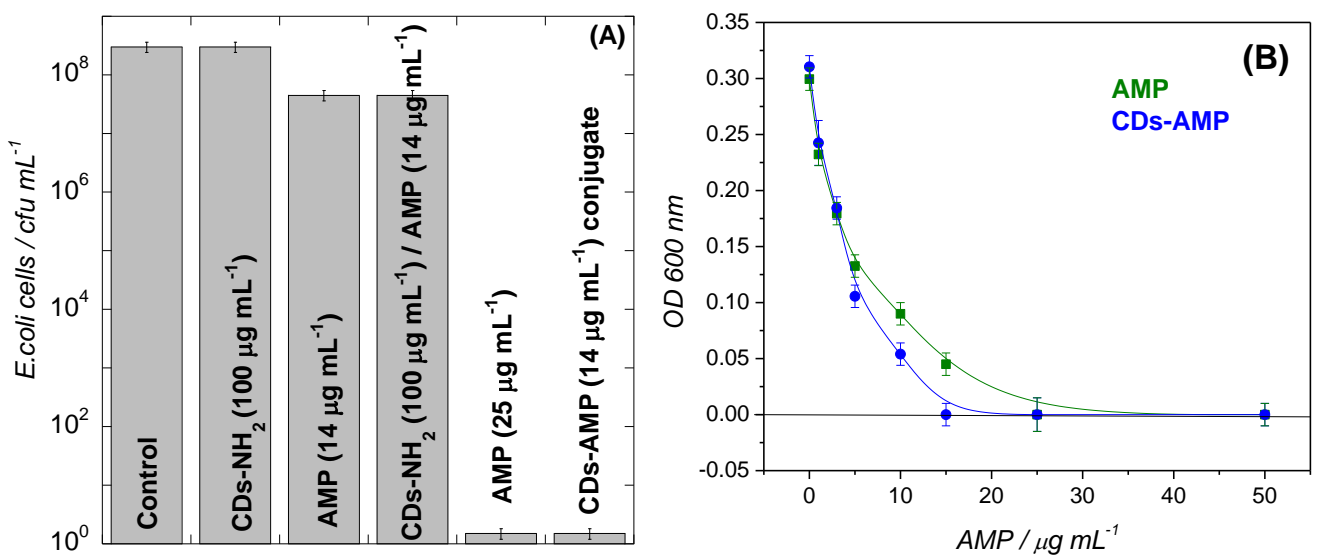

Figure 6. (A) Comparison of the antibacterial activity of $\mathrm{CDs}-\mathrm{NH}_{2}$, free AMP, AMP mixed with CDs- $\mathrm{NH}_{2}$ with respective to CDs-AMP conjugate against $E$. coli $\mathrm{K} 12-\mathrm{MG} 1655$. (B) Change of 
$\mathrm{OD}_{600 \mathrm{~m}}$ after $6 \mathrm{~h}$ in the absence and presence of various concentrations of AMP $\left(0-100 \mu \mathrm{g} \mathrm{mL}^{-}\right.$

${ }^{1}$ ). The error bars represent the standard deviation of three independent experiments.

\section{Antibacterial properties under visible light irradiation (PDT)}

Furthermore, we have investigated the ability of $\mathrm{CDs}-\mathrm{NH}_{2}$ and CDs-AMP to generate singlet oxygen $\left({ }^{1} \mathrm{O}_{2}\right)$ under visible light illumination for antimicrobial particle-based photodynamic therapy (PPDT). The results indicated that the amount of ${ }^{1} \mathrm{O}_{2}$ increased with exposure time and visible light lamp intensity (Fig. S15A).

The efficiency of CDs- $\mathrm{NH}_{2}$ and CDs-AMP to kill bacterial cells was investigated by irradiating a suspension of E. coli K12 - MG $1655\left(1 \times 10^{6} \mathrm{cfu} \mathrm{mL}^{-1}\right)$ in the presence of CDs$\mathrm{NH}_{2}$ and CDs-AMP at different concentrations for 10 or 20 min at $0.3 \mathrm{~W}$.

As seen in Fig. 7, the photodynamic bacterial killing effect of $\mathrm{CDs}-\mathrm{NH}_{2}$ depends on the concentration of CDs- $\mathrm{NH}_{2}$; at a concentration of $400 \mu \mathrm{g} \mathrm{mL}$, the CDs- $\mathrm{NH}_{2}$ were able to reduce E. coli cells viability by $4 \log _{10}$ after $20 \mathrm{~min}$ of irradiation. This is in agreement with the amount of singlet oxygen produced using $\mathrm{CDs}-\mathrm{NH}_{2}$. A similar result was reported by Meziani et al.[10]
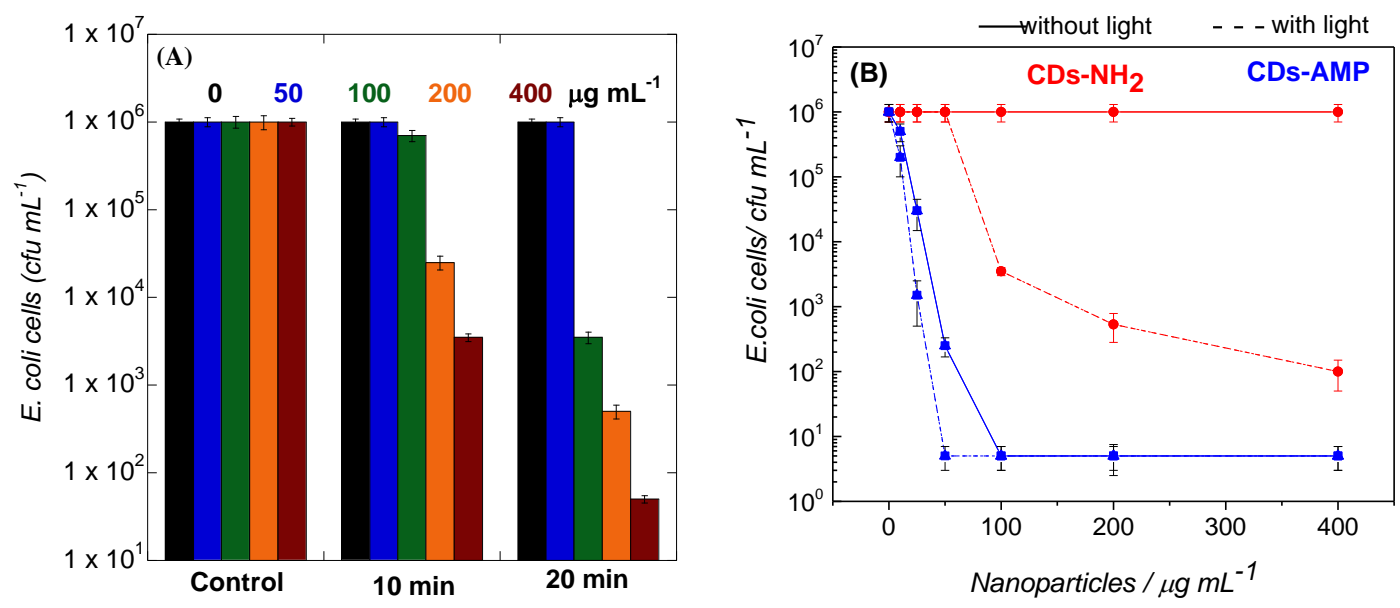

Figure 7. (A) Photodynamic efficiency of CDs- $\mathrm{NH}_{2}$ for the inactivation of E. coli K12-MG 1655 upon irradiation at $0.3 \mathrm{~W}$ for 10 and $20 \mathrm{~min}$. (B) Influence of the $\mathrm{CDs}^{-\mathrm{NH}_{2}}$ and CDs-AMP concentration on the treatment efficiency of $E$. coli without (solid lines) and with (dash lines) visible light illumination ( $20 \mathrm{~min}, 0.3 \mathrm{~W}$ ). The error bars represent the standard deviation of three independent experiments. 
Furthermore, the exposure of CDs-AMP to visible light enhanced the bactericidal activity of the conjugate (Fig. 7B). The generation of ROS species by the $\mathrm{CDs}-\mathrm{NH}_{2}$, including singlet oxygen $\left({ }^{1} \mathrm{O}_{2}\right)$ may be a possible explanation for the substantial enhancement of the bactericidal activity of CDs-AMP. The CDs-AMP conjugate retained partially the intrinsic theranostic properties of CDs- $\mathrm{NH}_{2}$, as show in Fig. S15B. Therefore, the CDs-AMP conjugate can be used as a multifunctional nanoplatform based on the combined therapeutic killing of antibiotic with visible light triggered photodynamic effects.

\section{Conclusion}

In summary, carbon dots show considerable potential in biomedical applications, particularly for bacteria eradication. The data presented here demonstrated that amine-functionalized carbon dots $\left(\mathrm{CDs}-\mathrm{NH}_{2}\right)$ can be successfully used as antimicrobial agent and/or as carrier for the delivery of antimicrobial drugs. Ampicillin-modified CDs were found to be very effective in killing $E$. coli cells, due to the antibacterial function of the ampicillin, combined with the advantage of antimicrobial photodynamic therapy of the CDs. The immobilization of AMP to CDs surface improved its stability and enhanced its bactericidal activity. Furthermore, the photodynamic properties of the CDs enhanced more their bactericidal function upon visible light irradiation. A possible explanation for the effective bacteria killing could be the affinity of CDs to attach on the $E$. coli cells wall, which is more easily exposed to the action of drug molecules and to oxygen reactive species (e.g. singlet oxygen), causing the disruption of cell membrane integrity.

\section{Acknowledgements}

Financial support from the Centre National de la Recherche Scientifique (CNRS), the University of Lille, the Hauts-de-France region, the CPER "Photonics for Society", the Agence Nationale de la Recherche (ANR) and the EU union through FLAG-ERA JTC 2015-Graphtivity, and the Marie Sklodowska-Curie action (H2020-MSCA-RISE-2015, PANG-690836) are acknowledged. We kindly thank Dr. Corentin Spriet, Bio Imaging Center Lille and Dr. David Fournier, UMET, for providing the technical environment to perform the confocal and fluorescence measurements, respectively. 


\section{References}

[1] V. Turcheniuk, V. Raks, R. Issa, I.R. Cooper, P.J. Cragg, R. Jijie, N. Dumitrascu, L.I. Mikhalovska, A. Barras, V. Zaitsev, R. Boukherroub, S. Szunerits, Diamond Related Mater., 57 (2015) 2-8.

[2] S. Boulahneche, R. Jijie, A. Barras, F. Chekin, S.K. Singh, J. Bouckaert, M.S. Medjram, S. Kurungot, R. Boukherroub, S. Szunerits, J. Mater. Chem. B, 5 (2017) 6557-6565.

[3] R. Jijie, T. Dumych, L. Chengnan, J. Bouckaert, K. Turcheniuk, C.-H. Hage, L. Heliot, B. Cudennec, N. Dumitrascu, R. Boukherroub, J. Mater.Chem. B, 4 (2016) 2598-2605.

[4] H. Maaoui, R. Jijie, G.-H. Pan, D. Drider, D. Caly, J. Bouckaert, N. Dumitrascu, R. Chtourou, S. Szunerits, R. Boukherroub, J. Colloid Interface Sci., 480 (2016) 63-68.

[5] K. Turcheniuk, C.-H. Hage, J. Spadavecchia, A.Y. Serrano, I. Larroulet, A. Pesquera, A. Zurutuza, M.G. Pisfil, L. Héliot, J. Boukaert, J. Mater. Chem. B, 3 (2015) 375-386.

[6] C.-I. Weng, H.-T. Chang, C.-H. Lin, Y.-W. Shen, B. Unnikrishnan, Y.-J. Li, C.-C. Huang, Biosens. Bioelectron., 68 (2015) 1-6.

[7] S. Nandi, M. Ritenberg, R. Jelinek, Analyst, 140 (2015) 4232-4237.

[8] Q. Wang, X. Huang, Y. Long, X. Wang, H. Zhang, R. Zhu, L. Liang, P. Teng, H. Zheng, Carbon, 59 (2013) 192-199.

[9] L. Cao, S.-T. Yang, X. Wang, P.G. Luo, J.-H. Liu, S. Sahu, Y. Liu, Y.-P. Sun, Theranostics, 2 (2012) 295-301.

[10] M.J. Meziani, X. Dong, L. Zhu, L.P. Jones, G.E. LeCroy, F. Yang, S. Wang, P. Wang, Y. Zhao, L. Yang, ACS Appl. Mater. Interfaces, 8 (2016) 10761-10766.

[11] V.N. Mehta, S. Jha, S.K. Kailasa, Mater. Sci. Eng. C, 38 (2014) 20-27.

[12] Y.-P. Sun, B. Zhou, Y. Lin, W. Wang, K.A.S. Fernando, P. Pathak, M.J. Meziani, B.A. Harruff, X. Wang, H. Wang, J. Am. Chem. Soc., 128 (2006) 7756-7757.

[13] D. Zhong, Y. Zhuo, Y. Feng, X. Yang, Biosens. Bioelectron., 74 (2015) 546-553.

[14] Q. Dou, X. Fang, S. Jiang, P.L. Chee, T.-C. Leed, X.J. Loh, RSC Adv., 5 (2015) 4681746822.

[15] A.S. Krishna, C. Radhakumary, M. Antony, K. Sreenivasan, J. Mater. Chem. B, 2 (2014) 8626-8632.

[16] M. Thakur, S. Pandey, A. Mewada, V. Patil, M. Khade, E. Goshi, M. Sharon, J. Drug Delivery, 2014 (2014) 282193. 
[17] C.-W. Lai, Y.-H. Hsiao, Y.-K. Peng, P.-T. Chou, J. Mater. Chem., 22 (2012) 14403-14409.

[18] N. Gogoi, D. Chowdhury, J. Mater. Chem. B, 2 (2014) 4089-4099.

[19] C. Fowley, N. Nomikou, A.P. McHale, B. McCaughan, J.F. Callan, Chem. Commun., 49 (2013) 8934-8936.

[20] Y. Choi, S. Kim, M.H. Choi, S.R. Ryoo, J. Park, D.H. Min, B.S. Kim, Adv. Funct. Mater., 24 (2014) 5781-5789.

[21] W. Bing, H. Sun, Z. Yan, J. Ren, X. Qu, small, 12 (2016) 4713-4718.

[22] J. Liu, S. Lu, Q. Tang, K. Zhang, W. Yu, H. Sun, B. Yang, Nanoscale, 9 (2017) 7135-7142.

[23] J. Yang, X. Zhang, Y.-H. Ma, G. Gao, X. Chen, H.-R. Jia, Y.-H. Li, Z. Chen, F.-G. Wu, ACS Appl. Mater. Interfaces, 8 (2016) 32170-32181.

[24] N. Sattarahmady, M. Rezaie-Yazdi, G. H. Tondro, N. Akbari, J. Photochem. Photobiol. B, 166 (2017) 323-332.

[25] X. Xu, R. Ray, Y. Gu, H.J. Ploehn, L. Gearheart, K. Raker, W.A. Scrivens, J. Am. Chem. Soc., 126 (2004) 12736-12737.

[26] P. Juzenas, A. Kleinauskas, P. George Luo, Y.-P. Sun, Appl. Phys. Lett., 103 (2013) 063701.

[27] W.C. Huang, P.J. Tsai, Y.C. Chen, Small, 5 (2009) 51-56.

[28] J. Lu, J.-x. Yang, J. Wang, A. Lim, S. Wang, K.P. Loh, ACS Nano, 3 (2009) 2367-2375.

[29] L. Zheng, Y. Chi, Y. Dong, J. Lin, B. Wang, J. Am. Chem. Soc., 131 (2009) 4564-4565.

[30] C. Liu, P. Zhang, F. Tian, W. Li, F. Li, W. Liu, J. Mater. Chem., 21 (2011) 13163-13167.

[31] H. Huang, C. Li, S. Zhu, H. Wang, C. Chen, Z. Wang, T. Bai, Z. Shi, S. Feng, Langmuir, 30 (2014) 13542-13548.

[32] B. Bhushan, S.U. Kumar, P. Gopinath, J. Mater. Chem. B, 4 (2016) 4862-4871.

[33] H. Zhu, X. Wang, Y.-J. Li, Z. Wang, F. Yang, X. Yang, Chem. Commun., (2009) 51185120.

[34] S. Karthik, B. Saha, S.K. Ghosh, N.D.P. Singh, Chem. Commun., 49 (2013) 10471-10473.

[35] S. Pandey, A. Mewada, M. Thakur, A. Tank, M. Sharon, RSC Adv., 3 (2013) 26290-26296.

[36] S. Pandey, M. Thakur, A. Mewada, D. Anjarlekar, N. Mishra, M. Sharon, J. Mater.Chem. B, 1 (2013) 4972-4982.

[37] H. Huang, J.-J. Lv, D.-L. Zhou, N. Bao, Y. Xu, A.-J. Wang, J.-J. Feng, RSC Adv., 3 (2013) 21691-21696. 
[38] C. Zhu, J. Zhai, S. Dong, Chem. Commun., 48 (2012) 9367-9369.

[39] S. Sahu, B. Behera, T.K. Maiti, S. Mohapatra, Chem. Commun., 48 (2012) 8835-8837.

[40] L. Wang, H.S. Zhou, Anal. Chem., 86 (2014) 8902-8905.

[41] W. Lu, X. Qin, S. Liu, G. Chang, Y. Zhang, Y. Luo, A.M. Asiri, A.O. Al-Youbi, X. Sun, Anal. Chem., 84 (2012) 5351-5357.

[42] S. Liu, J. Tian, L. Wang, Y. Zhang, X. Qin, Y. Luo, A. Asiri, A.O. Al-Youbi, X. Sun, Adv. Mater., 24 (2012) 2037-2041.

[43] Y. Yang, J. Cui, M. Zheng, C. Hu, S. Tan, Y. Xiao, Q. Yang, Y. Liu, Chem. Commun., 48 (2012) 380-382.

[44] S. Zhu, Q. Meng, L. Wang, J.-R. Zhang, Y. Song, H. Jin, K.-Q. Zhang, H. Sun, H. Wang, B. Yang, Angew. Chem. Int. Ed., 52 (2013) 3953-3957.

[45] G. Jarre, S. Heyer, E. Memmel, T. Meinhardt, A. Krueger, Beilstein J. Org. Chem., 10 (2014) 2729-2737.

[46] Z.L. Wu, P. Zhang, M.X. Gao, C.F. Liu, W. Wang, F. Leng, C.Z. Huang, J. Mater. Chem. B, 1 (2013) 2868-2873.

[47] X. Jia, J. Li, E. Wang, Nanoscale, 4 (2012) 5572-5575.

[48] J. Niu, H. Gao, J. Lumin., 149 (2014) 159-162.

[49] H. Wang, P. Gao, Y. Wang, J. Guo, K.-Q. Zhang, D. Du, X. Dai, G. Zou, APL Mater., 3 (2015) 086102.

[50] X. Zhang, Y. Zhang, Y. Wang, S. Kalytchuk, S.V. Kershaw, Y. Wang, P. Wang, T. Zhang, Y. Zhao, H. Zhang, ACS Nano, 7 (2013) 11234-11241.

[51] L. Shi, J.H. Yang, H.B. Zeng, Y.M. Chen, S.C. Yang, C. Wu, H. Zeng, O. Yoshihito, Q. Zhang, Nanoscale, 8 (2016) 14374-14378.

[52] Z. Yang, M. Xu, Y. Liu, F. He, F. Gao, Y. Su, H. Wei, Y. Zhang, Nanoscale, 6 (2014) 18901895.

[53] T. Wang, X. Jiang, ACS Appl. Mater. Interfaces, 5 (2013) 1190-1196.

[54] B. Saha, J. Bhattacharya, A. Mukherjee, A. Ghosh, C. Santra, A.K. Dasgupta, P. Karmakar, Nanoscale Research Letters, 2 (2007) 614.

[55] B. Saha, J. Bhattacharya, A. Mukherjee, A. Ghosh, C.R. Santra, A.K. Dasgupta, P. Karmakar, Nanoscale Res. Lett., 2 (2007) 614. 
[56] W. Wu, S. Wieckowski, G. Pastorin, M. Benincasa, C. Klumpp, J.P. Briand, R. Gennaro, M. Prato, A. Bianco, Angew. Chem. Int. Ed., 44 (2005) 6358-6362.

[57] A.N. Brown, K. Smith, T.A. Samuels, J. Lu, S.O. Obare, M.E. Scott, Appl. Environm. Microbiol., 78 (2012) 2768-2774.

[58] R. Jijie, A. Barras, F. Teodorescu, R. Boukherroub, S. Szunerits, Mol. Syst. Des. Eng., 2 (2017) 349-369.

[59] A. Rai, A. Prabhune, C.C. Perry, J. Mater. Chem., 20 (2010) 6789-6798. 